\title{
JOURNAL.RU
}

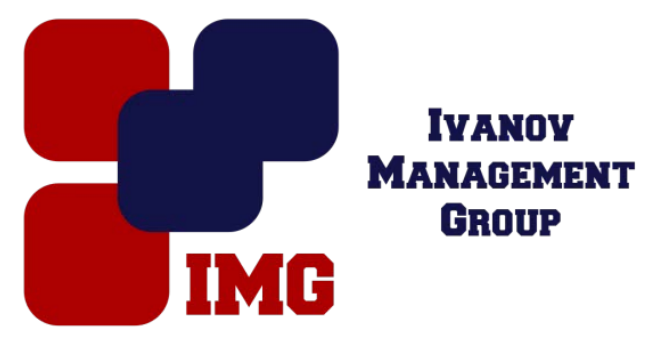

Шубина М.М., Леонова М.Ю. Институт сферы обслужсивания и предпринимательства (филиал) Донского государственного технического университета в г. Шахты

Шахты, Россия

doi: 10.18411/lj-30-04-2017-2-08

idsp 000001:lj-30-04-2017-2-08

\section{Проблема современной молодежной культуры в контексте смены поколений}

\begin{abstract}
Аннотация
Статья посвящена анализу молодежной культуры, определению подходов к возрастной периодизации молодежи. Проведен краткий анализ работ отечественных и зарубежных авторов в рамках исследуемой проблемы. Описаны модели смены поколений. Рассмотрены вопросы «клипового» мышления и инфантилизации взглядов в современной культуре.

Ключевые слова: культура, молодежь, «клиповое» мышление, смена поколений, гендерные особенности.

Современная молодежная культура является очень многогранным и динамичным явлением. Хотя само ее существование до определенного времени ставилось под сомнение само ее существование.

Существуют разные подходы к возрастной периодизации молодости. И если биологический подход ограничивает юношеский возраст от 20 до 35 лет, то социальные, психологические и культурные рамки сильно зависит от индивидуальных и общественных факторов. Так или иначе, молодость занимает продолжительный период жизни и является важным этапом в социальной жизни личности.

Для современного общества характерно расширение возрастных границ молодости. Таким образом, молодежная культура охватывает большую часть населения.
\end{abstract}


Проблема периодизации процессов смены поколений и соответственно молодежной культуры разработана достаточно хорошо. Наибольший интерес представляет теория периодизации поколений, разработанная У.Штраусом и Н. Хоувом. Исследователи разработали модель четырехчасного поколенческого цикла и выдвинули теорию циклической сменяемости поколений[2].

Данная теория призвана прогнозировать социальные свойства представителей поколений, которые в том числе влияют на направленность господствующей молодежной культуры.

Первая часть цикла «Подъем», этот этап характеризуется слабым индивидуализмом. Вторая часть цикла - «Пробуждение», на данном этапе общественная экспансия в область частной жизни порождает протестные процессы. Третий этап - «Спад» характеризуется разочарованием в общественных институтах и усилением индивидуализма. Четвертый этап наступает с окончательным разрушением институций общества начатом на предыдущем этапе. Этап носит название «Кризис». Государственная власть возвращается к управлению общества. Культура меняет направление и служит нуждам общества, и люди постепенно начинают осознавать себя в качестве членов некой более крупной группы. Для этапа характерно возрождение патриотических настроений. Адаптируя данную теорию к современному состоянию общества, поколение родившихся с 1984 по 2003 гг. (далее поколение Y) соответствует кризисному поколению. В данный момент, согласно данной теории происходит смена поколений и к активной общественной жизни подключается поколение рожденных после 2003 года, которых, как правило, обозначают как поколение Z. В зарубежной литературе они носят название поколения домоседов или молчаливого поколения.

Дальнейший анализ социокультурных характеристик поколений позволяет выделить основные проблемы формирования молодежной культуры. Отчасти эти проблемы связаны с цикличным развитием общества, но значительная их часть проистекает из-за развития коммуникационных технологий.

Главной особенностью поколения $\mathrm{Y}$ является вовлеченность в информационных технологии и господство философской парадигмы миллениума, для которого характерно стремление максимально оттянуть наступление взрослости и концепции вечной молодости, что не исключает наличия депрессивных периодов. Это стремление продлить юность выражается в инфантилизации взглядов, распространенности юношеских увлечений в 
зрелом возрасте, частой смене работы и профессий, а так же многих других особенностях.

Исследовавшая вопросы смены поколений в нашей стране Е. Шамис отмечает, что «у поколения Y нет и не может быть героев, однако есть кумиры»[3], эти люди иначе понимают трудовую и общественную культуру. Ролевая модель этого поколения предписывает направленность на изменение работы под личную жизнь, а не наоборот.

Для межличностных отношений характерен максимализм и бескомпромиссность. Усиливаются процессы уравнивания гендерных ролей, что выражается в появлении большого количества женских героических образов в кино, литературе и видеоиграх[1].

Не менее значительное влияние на общественную культуру оказывает сформированность у этого поколения так называемого «клипового мышления». Истоками данной проблемы является преобладание в информационном потоке потребляемым современным человеком коротких информационных сообщений, что делает затруднительным аналитические операции и восприятия крупных массивов данных. Данные изменения носят адаптивный характер. Современные продукты массовой культуры, как правило, создаются для клипового потребителя

Следующее за поколением $\mathrm{Y}$ поколение $\mathrm{Z}$ характеризуется еще более глубокой вовлеченностью в информационные технологии. Этот факт обуславливает значительное место в молодежной культуре вопросов взаимоотношения в виртуальной среде и сниженную социальную активность в реальной жизни. Снижение социальной активности можно отметить уже сейчас, однако анализ развития общественной и культурной активности данного поколения носит большей частью прогностический характер. Несмотря на это некоторыми исследователями отмечается особенно сильно проявляемый нарциссизм, эгоизм, помимо этого отмечается усиление негативных тенденций наблюдаемых у поколения Ү. Так, отмечается большая зависимость от электронных устройств и сетевых сервисов, сниженную концентрацию внимания и как следствие уменьшения возможностей к восприятию больших объемов информации.

Таким образом, основными проблемами молодежной культуры в настоящий момент и в обозримом будущем является неопределенность места человека в жизни общества и проблемы адаптации к информационному потоку 
В современной культуре происходит переоценка ценностей и смена общественных и семейных ролей.

1. Васильева Н.Ю. Женский образ героя в современном кинематографе: структурнофункциональный анализ // Международный студенческий научный вестник. - 2016. - № 4 (часть 5) - С. 662-662.

2. Тулган Б.Не всем достанется приз. Как управлять поколением Ү. - М.: МИФ, 2017. $256 \mathrm{c}$.

3. Шамис Е., Никонов Е.. Теория поколений: Необыкновенный Икс. - М.: Синергия, 2016. $140 \mathrm{c}$. 